\title{
VIOLENCE IN WHITMAN'S "WHEN LILACS LAST IN THE DOORYARD BLOOM'D”
}

\author{
Patricia Lee Yongue
}

WALT WHITMAN ONCE DESCRIBED Abraham Lincoln's assassination as the "crowning crime of the Rebellion." The description, though full of the poet's outrage, nevertheless parlays its oxymoron into a dialectic as characteristic of Whitman's poetry as organic imagery. In "When Lilacs Last in the Dooryard Bloom'd," a particularly stunning example of his dialectic, nascent spring and the "powerful western fallen star" (that serves as a metaphor for Lincoln in death) evoke powerful, conflicting emotions in the poet which transport him back to that first and continuously remembered rebellion signaling the death of his own innocence. A childlike grief for a lost personal hero transformed into the absorbing adult love for mortal man and for self occasions, in outwardly Wordsworthian fashion, the romantic poet's discovery that death must indeed be the "dark mother" of beauty, the grim but perfecting element of life. ${ }^{2}$ For Whitman, as for Wordsworth in The Prelude, there will always be greater joy because there was once great grief:

When lilacs last in the dooryard bloom'd, And the great star early droop'd in the western sky in the night, I mourn'd, and yet shall mourn with ever-returning spring. ${ }^{3}$ (1l. 1-3)

In the intentional ambiguity of the adverb "last," in the gentle apostrophe to "ever-returning spring" (1. 4), in the intimation that "mourn" is also "morn," and in the splendid assonance of "bloom'd" and "droop'd," the mature poet quickly improvises a harmony between life and death that germinates in the dialectic of his poem. Thus, what on the purely historical level is a man's unnatural death at the hands of another man-a violent "crime" - becomes on more symbolic levels a natural, necessary creative event.

Throughout "Lilacs," the death that produces all the new life is the outcome of human acts of violence. This violence purposely wrought by man mirrors that which is inevitably wreaked upon him by his own mortality. Like death, awful and unnatural in its immediate aspect, the violence-also like death-becomes an integral, hence natural, part of physical, psychological, and poetic growth. ${ }^{4}$ For the Whitman of Drum-Taps, moreover, the tremendous violence and "carnage" of the Civil War-it was then the country's costliest war in terms of human life-and its culmination in Lincoln's premature death precipitated the maturity of the nation and its poet. The "torn and bloody" battle flags in "Lilacs" that are "Borne through the smoke" with their "splinter'd and broken" staffs (11. 173-176), suggestive 
as much of first intercourse, parturition, and circumcision as of crucifixion, are the first signs of new life. And the moving, "arriving" coffin carrying the corpse of the slain Lincoln, who represents all those who died so violently in battle, is the image of the poem itself.

Although Whitman emphasizes the explicit and bloody violence of battle (Chant 15) and recalls, less explicitly, the violence of Lincoln's death, he does not attribute violence exclusively to others. The aggrieved poet of "Lilacs," in fact, is the sole perpetrator of the only real, if subtle, violence committed during the poem's present action. The phallic flags carried by the armies are already mutilated; the soldiers are already "slain" and are already "corpses" and "white skeletons." Not one of the soldiers is described in the act of killing or destroying. Lincoln himself is a fallen star; there is no direct reference to the assassination. Only the poet, curiously enough, acts in a manner that may be construed as physically aggressive and even violent. Only he destroys, and his very destructiveness is what amounts to the "crowning crime" of his own rebellion.

Chant 2 of "Lilacs" repeats the initial surge of the poet's grief for the dead President:

\author{
O powerful western fallen star! \\ $\mathrm{O}$ shades of night $-\mathrm{O}$ moody, tearful night! \\ $\mathrm{O}$ great star disappear'd-O the black murk that hides the star! \\ $\mathrm{O}$ cruel hands that hold me powerless - O helpless soul of me! (11. 7-11)
}

The grief here is understandably tortured, despairing, angry. It is an impassioned outburst or rebellion that is natural in one newly stricken and frustrated by the senselessness of his loss. At this point, too, the formless force of death-the "black murk"-seems omnipotent, more powerful than the "powerful" western star who was most recently one of the mourner's gods, and infinitely more powerful than the "powerless" poet whose mind and imagination have not yet come of age to be the god that will illuminate the darkness and conquer the evil of death.

In a dramatic shift in tone, however, Chant 3 suddenly quells the torrent of the previous chant by initiating a serene, almost pastoral narrative:

In the dooryard fronting an old farm-house near the white-wash'd palings, Stands the lilac-bush tall-growing. . . . (11. 12-13)

But despite its overlay of serenity and life, the chant ends with what is unmistakably an act of violence. After describing the "tall-growing" lilac bush with its "heart-shaped leaves of rich green" and its "perfume strong," the poet records his first physical response to the bush's allure: "A sprig with its flower I break" (1. 17). The assault is repeated in Chant 7, when the poet decides that lilacs, more than the traditional biblical "roses and early lilies," should be used to "cover . . over" death. ${ }^{5}$ 
But mostly and now the lilac bush that blooms the first, Copious I break, I break the sprigs from the bushes . . (11. 50-51)

Obviously the breaking of a sprig of lilac, or even "copious" sprigs, does not equal in severity the shooting of a president or the killing of one hundred and ninety thousand men in war. Seen in any light, including the light of Whitman's strenuous pacificism, the comparison is in fact quite ludicrous. Nonetheless, Whitman declares poetically, breaking the sprig is a distinctly violent act committed by man against nature, an act which contradicts the thrust of nature's force represented by the "tall growing" lilac bush. But it is also a deed that is to be identified with the assassin's crime, the lover's brutality, and the soldier's gruesome task. ${ }^{6}$

Presumably Whitman could have conveyed the same plot information differently, in a way that would have mitigated the sense of transgression and the association with the violence of man against man. "Break," however, is a noticeably harsh word that connotes aggression and destruction. ${ }^{7}$ And in a poem that ostensibly commemorates the end of an era of personal as well as national crisis and hostility and the beginning of new modes of fraternity, the fledgling poet's attack upon the lilac bush is a significant event. When the verb "break" is used again, this time in adjectival form to denote violence already executed - "the staffs all splinter'd and broken" (1.176)-the sprig(s) of lilac that the poet breaks clearly reveal, through the visual and alliterative $(\mathrm{s} / \mathrm{b})$ pattern, their emphasis on destruction. The poet has responded to violence with his own violence, muted though it is in comparison to assassination and war, and such a response has its justification.

The narrative reenactment of the poet's/poem's growth, which is anticipated in Chant 1 , begins more formally in Chant 3 in the dooryard of an old farmhouse where the lilac grows new every year. In this suitably agrarian setting, the experiencing poet is a neophyte, while the narrating self introduced in the first chant is the mature poet (the narrator here refers to action already completed) who will repeat the experience as he commemorates it. Although this experiencing child is associated with the more civilized man of Chant 7, who together with his society acknowledges life's solemn events with flowers, he is in the isolated world of Chant 3 still a child and a primitive because his first act is simple, impulsive, and morally innocent. The pastoral site of the act reinforces this idea, while "farmhouse" itself evokes the image of man's earliest efforts to impose his civilization on nature. The youth breaks a single sprig of lilac in the dooryard of this old house, as opposed to the "copious" sprigs he breaks in Chant 7, when he has moved beyond the farm and is getting closer to the cities, to maturity, and ironically to a more adult expression of the same urge to violence. ${ }^{8}$

Just in the context of a personal and social immaturity-childhood-the breaking of the lilac sprig has psychological importance. The child is often 
violent and destructive before he is either sociable or creative. Such behavior is normal and consistent with 1) his sense of ownership and mastery of all that surrounds him, 2) his basic need to prove dominance in the face of increasing threats to that sense of supremacy, and 3) his frustration accompanying his intellectual innocence about a world that is showing more and more resistance to him. Even when the experiencing self approaches the cities and, by extension, civilization, society, and maturity, he is still not truly civilized. Barbarism is in this respect a necessary part of primitivism. ${ }^{9}$ When the poet breaks "copious" sprigs of lilacs, thereby suggesting a newfound security of fellowship, he is still demonstrating a fundamental intellectual insecurity about death. The lavish camouflage which his "loaded arms" bear to "cover ... over" "sane and sacred death" (Chant 7) is only camouflage.

In the context of the developing poet and the natural man, two of Whitman's favorite personae in Leaves of Grass, the breaking of the lilac sprig is likewise appropriate. Like the child, the poet and the man need to destroy - to destroy in order to dominate. For Whitman, even the natural man and the romantic poet, both of whom are intimate with nature, have a need to do more than absorb and be absorbed by nature. Man, including and perhaps especially the poet, must stand apart from nature, must show his superiority, must dominate. This first natural desire to dominate is necessarily accompanied by the impulse to "break" - or render subservient - what is initially perceived to be the vast power of the natural world. Although he may not at first fully comprehend what his impulse signifies, he is nevertheless compelled to obey that impulse. From the human and poetic perspective, then, his action against nature is most natural. His first response to the power of his own mortality - the "black murk"-will be similar.

The poet's act of violence resulting in the premature death of the lilac sprig thus defines his humanity, his participation in human activity, his need to be a child before he can be a man who is also a child. His development as a poet, with respect to violence, parallels the child's process of maturation/socialization. In addition to being a culturally and somewhat emotionally satisfying gesture of mourning, the breaking of the lilac sprig "with its flower" is the morning of poetic experience, a non-verbal phase of growth. Simultaneously, it is an expression of the human need to dominate and put into service the natural world, an effort equally necessary to the romantic poet's accession. Nature is what inspires the poet; but, like death, nature is also what the poet must subsequently control through language.

At the oedipal level, if such is to be acknowledged, the poet's assault specifically upon the "sprig with its flower" represents a subconscious desire to destroy nature as parent and to possess its creative power. The young poet is normally rebellious and wishes to break the rule of the very tradition which has attracted him ("the mastering odor") and to assume the status of reigning poet by releasing his own odor. But this young poet is also naturally too im- 
petuous and untutored. He has not yet discovered his own soul, craft, and scent, or the experience of fellowship. Insofar as the flower represents the beautiful proof of nature's creative potency, it metaphors the poem-in this case, however, another's poem. Thus the poet's first effort to be a poet involves not only the impulse to destroy, but also the impulse to appropriate. Until he can discover his own poetic identity and his own poem, that is, he tries to use other poets' poems, other lilacs, to speak for him. Like the young poet of Wordsworth's The Prelude, for whom "the bird / Which was the captive of another's toil" often became his own "prey" (Bk. I, 11. 319-322), the poet of Chant 3 of "Lilacs" is a usurper of the poetic soul of another. Indeed, there must be an element of irony in the poet's stance at the end of Chant 6 , when he addresses the "coffin that slowly passes": "I give you my sprig of lilac" (1. 45). At this point, his possession or ownership of the lilac is an essentially false possession (and his expression is still non-verbal), though to think of the lilac as "my sprig" is quite natural.

If maturity is to be consummated, the "time to murder" (in T. S. Eliot's words) must yield to the "time to create," and the barbarian must evolve into the truly civilized man. At the same time, however, the barbaric element must always be the initial element, so that every completed act of mature man contains, like the human body itself, its own history, its own evolutionary, organic process. This mature man - the most mature man and, hence, the complete man-is the poet. And every finished poetic act must contain its own youth-which is precisely what the Whitman poem does contain-and therefore that first instance of violence.

By Chant 10, the poet has gone beyond the limits of the ordinary, nonpoetic man who is by and large content to accept what has been created by others. He realizes that creation must issue from his own being and coexist in harmony with the creation of others.

O how shall I warble myself for the dead one there I loved?

And how shall I deck my song for the large sweet soul that has gone?

And what shall my perfume be for the grave of him I love?

Sea-winds blown from east and west,

Blown from the Eastern sea and blown from the Western sea, till there on the prairies meeting, These and with these and the breath of my chant, I'll perfume the grave of him I love. (11. 71-77)

In Chant 11, after journeying so long with the coffin, he recognizes at last that the "pictures" he will hang on the "burial-house" will be democratic, inclusive pictures. The Whitman poem will contain nature, farms, cities, all "the scenes of life." His pictures, like the journey he has just made, will be of "My own Manhattan" and "The varied and ample land, the South and the North ... / And ever the far-spreading prairies cover'd with grass and corn" (Chant 12, 11. 90-92). 
Finally, in Chant 16, the last chant of "Lilacs," the experiencing poet, now mature, comprehends his own soul and agrees to "unloosing the hold of my comrades' hands" (1. 186). Significantly, his relationship with the lilac bush has also changed; the violent phases have ended. Instead of breaking another sprig or "copious" sprigs, then, the poet now shows respect for the once assailable integrity of the bush:

Passing, I leave thee lilac with heart-shaped leaves,

I leave thee there in the door-yard, blooming, returning with spring. (11. 193-194)

The poet has made his own poem, as well as discovered a poetic identity, and so he leaves the lilac bush - both in the sense of departing from it because the mourning/morning rite is concluded, and in the sense of allowing it to remain intact, unassaulted, flowering. ${ }^{10} \mathrm{He}$ has entered into the final creative phase of his experience and into a fine awareness of the separateness and togetherness of himself, the "gray-brown" solitary thrush, the fallen star, and the lilac: "Lilac and star and bird twined with the chant of my soul" (1. 205). He has his own voice now, the "tallying chant"; there is no need to violate or to destroy the voice of another-until the next spring, the next time he begins the poetic process.

Despite this apparent reconciliation of varous conflicts and the accession to human and poetic maturity, however, the most disturbing ethical issue remains unresolved. ${ }^{11}$ What of the violence itself? What of the terrible destruction of human life and nature accomplished during the Civil War? In effect, actually, the patterns and images of "When Lilacs Last in the Dooryard Bloom'd" seem at some levels to be justifying violence. Not just death, but also physical violence is necessary to creation. This idea, rendered thematically, is corroborated by the fact that Lincoln's death is represented only in terms of a natural phenomenon ("fallen star," etc.), and also by the fact that the assassination as a deliberate act of destruction is referred to only indirectly through the poem's historical context and metaphorically through the poet's breaking of the lilac sprig. Added to this is the inescapable shadow of Christ's crucifixion which designates that such violence is not only inevitable but also necessary to redemption and therefore sometimes morally acceptable. This notion, of course, contradicts Whitman's personal morality, which was basically Quaker, and extends the odd comparison between the poet's act of breaking the sprig and man's killing of his fellow man.

The comparison and its worrisome implications, however, do become an important part of the growth, crisis, and emerging moral view of the poet. Although he has learned somewhat of death and grief and the way in which they can lead to new life both inside and outside the poem, he cannot reconcile real violence. It was one thing to hear about war and then write about it magnanimously, as Whitman had done in the early Leaves of Grass (e.g., 
"Song of Myself"); it was quite another thing to see for himself the consequences of such violent behavior, as he did on his visits to hospitals harboring the Civil War wounded. The "soul and body trials of 'masculine young manhood" that he witnessed" on such visits, writes Justin Kaplan, "baffled understanding and description, made conventional piety blasphemous."12 This new experience and change of poetic attitude is recorded in "Lilacs," first in the narrative arrangement.

Whitman chooses to deal with Lincoln's assassination-the initial impulse of his poem-and executes his own little violence before he treats the Civil War itself. There is, of course, a basic logic to this chronology, in that it is his personal response to the death of a personal hero which brings him finally to the experience of fraternity and thus to a keener awareness of the threat to that fraternity embodied in the Civil War. Likewise, the process of advancing - of "passing" - in the present takes the poet back to the past in order to make him more that complete American defined in the Preface to the Leaves of Grass and elsewhere in the poems. But the same chronology also represents another discovery for the poet, one which forces him to face the limitations of his poetic identity and his medium.

It is significant that Whitman delays presenting his awful pictures of war until Chant 15, the penultimate chant, for purposes of dramatic contrast and denial. Prior to Chant 15, he discusses death primarily in metaphoric terms, and he also-especially in the long and luscious Chant 14 that parallels Chant 2 -discusses grief. The only violence that transpires is his own bit of violence against the alluring lilac bush. Now, however, that violence appears quaint and negligible in the presence of the effects of so much bloody violence and destruction; yet, it is very clear that the poet intends to simulate the violence of assassination and war. Chant 15, which catalogues the carnage, actually undermines as it poetically consummates the comparison.

What Whitman orchestrates so successfully is a modern music of discord and rebellion, but not of a rebellion necessarily against an external rule or reality alone. Like America during the Civil War, the poet's greatest break is with self, with the poet who once thought his poetry and himself mature but who had not yet encountered the cataclysmic results of war and who was therefore only a rube. Traditional readings of "Lilacs" emphasize the poet's growth and change; however, like the first reading provided here, most cherish the experience as the dramatization of the nativity of poetic being. In terms of the motif of violence, the poet of "Lilacs" can also be seen as an older poet who has discovered a certain falseness about and incompatibility with his prior self and poems. That original poet was perhaps too self-confident, too assured of the way of the world. His poems, hence, were at one level a simple act unresponsive in their ebullience to a less than simple reality. The experience which brought him to the point of rebellion against this earlier self challenged his notions of ultimate harmony. 
When lilacs last in the dooryard bloomed, Abraham Lincoln was killed and the event culminated a time of horror for Whitman the pacifist. War had revealed to him a side of living and dying he had never before seen, and this changed his perspective. No longer is the poet of Leaves of Grass insuperable; no longer is he or his poem the complete and unequaled equalizer. No longer is who he is and what he does the "acme of things accomplish'd." Even the record of his own break with his former self is not as momentous as the event which precipated it. His sort of violence, necessary and inevitable though it is to his poetic development, pales against the tremendous, inevitable violence of war. Only as poetry, the poet of "Lilacs" realizes, can that violence be represented as creative. Outside of the poem, outside of metaphors, there is simply no way to redeem or to justify the carnage. Whitman had not even seen the violence, only its aftermath. For him the "white skeletons" and "battle-corpses," the "bloody" mess, and the wailings of mothers, wives, and children-more like his own desperate grief in Chant 2 than that of the melodious thrush in Chant 14 -are inalterably frightful. The violence of war, of man against man, cannot be reconciled, will always remain the discordant, destructive force for which poetry offers no real antidote.

\section{The University of Houston}

\section{NOTES}

1 Letter to the Armory Square Hospital Gazette. Quoted in Justin Kaplan, Walt Whitman: A Life (New York: Simon and Schuster, 1980), p. 301.

2 Cf., The Prelude, Bk. XII, 11. 261-271: "When, in the blessed hours / Of early love, the loved one at my side, / I roamed, in daily presence of this scene, / Upon the naked pool and dreary crags, / And on the melancholy beacon, fell / A spirit of pleasure and youth's golden gleam, / And think ye not with radiance more sublime / For these remembrances, and for the power / They had left behind? So feeling comes in aid / Of feeling, and diversity of strength / Attends us, if but once we have been strong."

3 Quotations from "When Lilacs Last in the Dooryard Bloom'd" are from Leaves of Grass, Comprehensive Reader's Edition, ed. Harold W. Blodgett and Sculley Bradley (New York: New York University Press, 1965), pp. 328-337.

4 There are many fine studies of "Lilacs" as a poem specifically about the maturation of the poet, to which this study is of necessity a postscript. Among these studies are Richard P. Adams, "Whitman's 'Lilacs' and the Tradition of Pastoral Elegy," PMLA, 72 (June 1957), 479-487; Lyle Domina, "Whitman's 'Lilacs': Process of Self-Realization," ESQ 58 (1970), 124-127; Charles Clay Doyle, "Poetry and Pastoral: A Dimension of Whitman's 'Lilacs,"” WWR, 15 (December 1969), 242-245; W. P. Elledge, "Whitman's 'Lilacs' as Romantic Narrative," WWR, 12 (September 1966), 59-67. Evelyn Hinz's excellent study of the poem, "Whitman's 'Lilacs': The Power of Elegy," in Bucknell Review, 20 (Fall 1972), 35-54, does not deal with maturation per se; but, in its exploration of the poem's emotional/verbal reality it provides a reading not necessarily inconsistent with the others. Mutlu Konuk Blasing's "Whitman's 'Lilacs' and the Grammars of Time," PMLA, 97 (January 1982), 31-39, presents a fascinating 
discussion of the poem's time-consciousness and of the poet's growing awareness of time's erosive effect on form and of his need to be continuously modern.

5 Lilacs, according to Kaplan, had a personal significance for Whitman. They were a part of the familiar landscape of his youth in Long Island.

6 Psychoanalytic criticism associates the act on the unconscious level with castration. See Edwin Haviland Miller, Walt Whitman's Poetry: A Psychological fourney (New York: New York University Press, 1968), p. 189. Stephen A. Black, in Whitman's fourney into Chaos (Princeton: Princeton University Press, 1975), pp. 239-10, refers to a process of symbolic self-castration effected in the poem.

7 "Break" in the colloquial sense of "relief" may also be implied, insofar as the unfulfilled poet does find a measure of relief in aggression.

8 Miller (fourney, p. 189) quotes Maud Bodkin's association between spring and the "golden bough" (Frazer, Virgil) in order to connect Whitman's single sprig of lilac to the primitive stages of development.

9 This aspect of barbarism/primitivism is only slightly related to George Santayana's observations on Whitman in "The Poetry of Barbarism," Interpretations of Poetry and Religion (Gloucester, Mass.: Peter Smith, 1969), pp. 176-181.

10 It is possible that a double pun on "leave" is intended. To "leave" the lilac in the dooryard, in the context of "bequeath," would suggest control and ownership of the lilac still. To "leave," in a transformation of the intransitive verb meaning to bear leaves, would also imply control not only of the lilac but also of language.

11 Evelyn Hinz, "Elegy," perceptively does not see total reconciliation. Although the poet/man experiences emotional satisfaction through his response to death, he remains intellectually dissatisfied with the notion of death itself. Blasing, "Grammars," also views the poem as a response to a fact of life for which there is no consolation.

12 Kaplan, p. 278. 